\title{
Nucleolar and Spindle-Associated Protein 1
}

National Cancer Institute

\section{Source}

National Cancer Institute. Nucleolar and Spindle-Associated Protein 1. NCI Thesaurus.

Code C126505.

Nucleolar and spindle-associated protein 1 (441 aa, $49 \mathrm{kDa}$ ) is encoded by the human NUSAP1 gene. This protein is involved in mitotic spindle stabilization. 